\title{
Spatial and temporal trends in freshwater fish research: the case of three neotropical river basins from Goiás State, Central Brazil
}

\author{
Tendências espaciais e temporais da pesquisa de peixes de água doce: o caso de três \\ bacias hidrográficas neotropicais do estado de Goiás, Brasil Central
}

\section{Rodrigo Assis Carvalho ${ }^{1,2 *}$ (D) and Francisco Leonardo Tejerina-Garro ${ }^{3,4}$ (D)}

\begin{abstract}
${ }^{1}$ Departamento de Biologia, Universidade Estadual de Goiás - UEG, Campus Palmeiras de Goiás, Rua S-7, s/n, Bairro Sul, CEP 74190-000, Palmeiras de Goiás, GO, Brasil

${ }^{2}$ Programa de Pós-graduação Stricto Sensu em Recursos Naturais do Cerrado - RENAC, Universidade Estadual de Goiás - UEG, Campus de Ciências Exatas e Tecnológicas - Henrique Santillo, BR 153, 3105, Fazenda Barreiro do Meio, CEP 75132-400, Anápolis, GO, Brasil

${ }^{3}$ Centro de Biologia Aquática, Pontifícia Universidade Católica de Goiás - PUC Goiás, Av. Engler, s/n, Jardim Mariliza, CEP 74605-010, Goiânia, GO, Brasil

${ }^{4}$ Programa de Mestrado e Doutorado em Sociedade, Tecnologia e Meio Ambiente, Laboratório de Biodiversidade, Centro Universitário de Anápolis - UniEVANGÉLICA, Av. Universitária Km 3,5, Cidade Universitária, CEP 75083-515, Anápolis, GO, Brasil

*e-mail: decarvalho.ra@gmail.com
\end{abstract}

Cite as: Carvalho, R.A. and Tejerina-Garro, F.L. Spatial and temporal trends in freshwater fish research: the case of three neotropical river basins from Goiás State, Central Brazil. Acta Limnologica Brasiliensia, 2019, vol. 31, e25.

Abstract: Aim: In this paper, we conducted a scientometric analysis on published studies related to freshwater fish species at Goiás State to evaluate: $i$ ) their spatial and temporal trends; ii) areas of knowledge; iii) scientific journals where these papers were published and their comprehensiveness; $i v$ ) the role of institutions and financial support on fish research. Methods: Using Google Scholar and Lattes platform, we searched for scientific papers related to freshwater fish, and we extracted the following information of each paper: title, author and co-authors' name, number of authors, year, authors and co-authors' affiliation, journal, field/area of the research, and financial support. Results: We found 322 scientific papers related to Goiás State with a slightly growth in the number of publications over time. Most of these papers are related to Ecology, Systematic/Taxonomy and Fish Biology, and the participation of local institutions in these studies was mainly concentrated in Paraná River basin. Although most of funding were granted by agencies or institutions located outside Goiás State, the results showed that fish papers achieved a broad audience with publications in national and international journals with impact factor. Conclusions: Our study revealed that: 1) freshwater fish research at Goiás State has a slow increase trend; 2) there are gaps in Education, Conservation and Fisheries knowledge areas; 3 ) local institutions' contribution is spatially concentrated; 4) studies achieved a broad audience with many scientific papers published in journals with impact factor; 5) financial support was granted in most part by agencies or institutions located outside Goiás State. These findings suggest that despite achievements in freshwater fish research in this region, local investments in infrastructure, materials and human resources are still necessary to improve the production of studies.

Keywords: Tocantins-Araguaia basin; Goiás State; scientific papers; Paraná River. 
Resumo: Objetivo: Neste estudo, conduzimos uma análise cienciométrica dos estudos sobre peixes de água doce no estado de Goiás para avaliar: $i$ ) os seus padróes espaciais e temporais; $i$ ) as áreas de conhecimento; iii) os periódicos científicos onde estes estudos foram publicados e a sua abrangência; e iv) o papel das instituiçōes e do suporte financeiro nas pesquisas. Métodos: Utilizando o Google Scholar e a plataforma Lattes, levantamos os artigos relacionados a peixes de água doce, e extraímos as seguintes informações: título, nome dos autores, número de autores, ano, afiliação dos autores, periódico, área de conhecimento da pesquisa, e suporte financeiro. Resultados: Encontramos 322 artigos relacionados ao estado de Goiás com um pequeno crescimento no número de publicaçóes ao longo do tempo. A maioria das publicaçôes está relacionada com as áreas de Ecologia, Sistemática/Taxonomia e Biologia de Peixes, e a participação de instituiçôes locais nos estudos encontra-se concentrada na bacia do Rio Paraná. Embora a maioria dos financiamentos terem sido concedidos por instituiçóes localizadas fora do estado de Goiás, os resultados indicam que os estudos desenvolvidos atingiram ampla audiência com publicaçôes em diversos jornais com fator de impacto. Conclusóes: Nosso estudo revelou que: 1) a pesquisa sobre peixes de água doce no estado de Goiás cresce, mas em ritmo lento; 2) há lacunas em áreas do conhecimento como Conservação, Educação e Pesca; 3) a contribuição das instituiçôes locais é espacialmente concentrada; 4) os estudos atingiram ampla audiência; 5) os financiamentos foram concedidos em sua maioria por agências localizadas fora do estado. Apesar do recente avanço nas pesquisas sobre peixes de água doce na região, os investimentos em infraestrutura, materiais e recursos humanos ainda são necessários como forma de incrementar a produção dos estudos na regiáo.

Palavras-chave: Bacia Tocantins-Araguaia; Estado de Goiás; artigos científicos; Rio Paraná.

\section{Introduction}

Brazil is considered a top biodiversity-rich country (megadiverse); it harbors between 9 to $10 \%$ of all earth species (Mittermeier et al., 1997; Lewinsohn \& Prado, 2005), including a great diversity of freshwater fish species (2587 species, Buckup et al., 2007). Since Rio Earth Summit 1992, Brazil has adopted environmental policies favoring the sustainable development (Ferreira et al., 2014; Loyola, 2014), monitoring forests and reducing deforestation levels (Hansen et al., 2013). Nevertheless, in recent years, misguided choices discordant of the scientific findings were made by Brazilian decision makers creating a real abyss between conservation science and environmental policies (Azevedo-Santos et al., 2017). One of these controversial policy decisions is the alteration of environmental policy that regulates forest deforestation and conservation, the "Forest Code" law (Metzger et al., 2010; Soares-Filho et al., 2014). According to Casatti (2010) and Magalhães et al. (2011) changes made in this law increase i) the removal of riparian vegetation and the degradation of water quality in freshwater systems, influencing on fish species survival and reproduction and ii) the potential occurrence of non-native species which compete with native species. Additionally, policies encouraging hydropower damming, such as Belo Monte Dam, even against all criticisms of the scientific community (Santos \& Hernandez, 2009; Scarano et al., 2012; Fearnside, 2017), also affects Brazilian freshwater fishes. To avoid such misguided decisions that often transgress the biological context, Azevedo-Santos et al. (2017) suggest that decision makers should be supported by translation scientists, science advisors and scientific committees to create public policies for sustainable development. This support should also include studies that offer a complete picture of research data and their trends on relevant fields of knowledge.

Dias et al. (2016) pointed out that studies about freshwater stream's fish assemblages grew exponentially in a period of 25 years (1987-2012), but they are unevenly distributed among Brazilian regions and often represent projects of short-term funding. Additionally, the spatial distribution of fish studies is influenced by geopolitical boundaries, that is, many Brazilian watercourses (mainly rivers) frequently transgress national or regional geopolitical boundaries hampering conservation efforts for freshwater systems (Allan et al., 1997; Carvalho \& Tejerina-Garro, 2015), influencing on where and how the investments are done. Although the drainage areas of river basins are considered the appropriate spatial scale for the development of scientific studies and conservation actions at freshwater habitats (Pollard \& Huxham, 1998; Moss, 2000), considering national or regional geopolitical boundaries to understand spatial and temporal trends of fish research is a relevant contribution to science efforts because investments frequently consider geopolitical boundaries instead of biological ones.

In this paper, we conducted a scientometric analysis on published scientific papers related to freshwater fish species at Goiás State territory. The main objective relies on identifying spatial and 
temporal trends of scientific papers published and their implications to fish research in this region. More specifically, we investigated aspects related to: $i)$ the association between temporal trends and the number of authors and institutions involved in these studies; ii) the main field of knowledge of these papers; iii) scientific journals where these articles were published and their comprehensiveness (impact on a broader audience); and $i v$ ) the role of institutions and financial support on freshwater fish research. Finally, we discussed possible perspectives for studies on freshwater fish fauna in this region and how this approach could be conducted for other localities. We choose to use Goiás State as our study case because it contains the headwaters of three important Brazilian river basins (Upper Araguaia, Upper Tocantins and Upper Paraná), and an expressive diversity of freshwater fish species. According to the worldwide database for fish species (FishBase), it is possible to find at least 135 species of freshwater fish species in Goiás State borders (Froese \& Pauly, 2018); even though the number of species found in this region can be higher than 135 (214 species in the Upper Paraná River basin, Tejerina-Garro et al., 2017; 135 species in the Upper Tocantins River basin and 37 in the Upper Araguaia River basin; Braudes-Araújo et al., 2019). Therefore, understanding how freshwater fish research was conducted until today in Goiás State's three main river basins is an important way to reveal trends and gaps and guide the development of future studies.

\section{Material and Methods}

To identify published scientific papers on freshwater fish we used the Google Scholar, which is a reliable and valid online bibliometric tool covering more journal than its competitors and registering journals from more countries and written in more languages (Delgado-López-Cózar \& Repiso-Caballero, 2013). Additionally, each Curriculum Vitae of Brazilian authors and co-authors resulting of Google Scholar research was checked in the Lattes platform from the Brazilian National Council for Scientific and Technological Development (CNPq, 2018) looking for published scientific papers. If a new scientific paper mentioned a new co-author, it was also checked his Curriculum Vitae.

The database was built considering scientific papers that: $i$ ) were published until the year of 2018; ii) had an available on-line file in the Portable Document Format (PDF); iii) were developed inside geopolitical boundaries of the Goiás State; iv) used fish data collected in this State. The Goiás State territory differs from other Brazilian ones because it includes the Federal District, capital of Brazil. Thus, we also included in the survey studies conducted within that District. The following keywords (single and combined) in English and Portuguese languages were used in the survey: Araguaia, Araguaia basin, Brasilia, Federal District, freshwater fish, Goiás, Goiás State, ichthyofauna, Paraná basin, Tocantins basin. The main combination of keywords used for our search were: (fish* AND Goiás state), (fish* AND Goiás AND Araguaia), (fish* AND Goiás AND Araguaia basin), (fish* AND Brasilia), (fish* AND Distrito Federal), (fish* AND Goiás AND Paraná), (fish* AND Goiás AND Paraná basin), (fish* AND Goiás AND Tocantins), (fish* AND Goiás AND Tocantins basin), (ichthyofauna AND Goiás State), (freshwater fish* AND Goiás). The same combinations were used in Portuguese language.

From each scientific paper, we extracted the following information: title, main author and co-authors' name, authors' number, year, authors and co-author' institution, journal of publication, field/area of research, and financial support. To collect these data, we adopted the following criteria: i) for main author and co-authors we registered their full name; ii) for institution we considered the name of each author's institution mentioned in the paper and each one was classified accordingly to its localization as local (inside Goiás State geopolitical boundaries) or external (Brazilian or international institutions located outside Goiás State geopolitical boundaries); iii) for journals we grouped them into two categories (with or without impact factor), and we used the journal name or its International Standard Serial Number (ISSN) to obtain its last Impact Factor consulting the Impact Factor List (2017/2018) available at Scijournal.org (2018); iv) for field/area of research we define it using the main objectives described in each paper, thus, one paper could be related to more than one field/area of research at the same time; papers related to internal and external morphology, physiology and behavior were grouped into one category called "Fish Biology"; v) for systematic/taxonomic papers, we considered only those using holotype/paratypes/topotypes collected inside Goiás State geopolitical boundaries; and vi) for financial support, we considered all project fundings and scholarships mentioned into the Acknowledgments section of each paper, and we classified these fundings as local (granted by an 
institution located inside Goiás State geopolitical boundaries) or external (granted by a Brazilian or international institutions located outside Goiás State geopolitical boundaries). The data collected included three river basins (Araguaia, Paraná and Tocantins) and it was organized in a dataset hereafter denominated Goiás dataset. When the research of a scientific paper was conducted in more than one basin, we considered this paper only one time for Goiás dataset and, consequently, the sum of scientific papers of the three river basins was higher than the number of scientific papers in Goiás dataset. We used descriptive analyses to reveal spatial and temporal trends of fish studies for Goiás State and by each of the river basins considered.

\section{Results}

We found 322 scientific papers related to Goiás State's freshwater fish. Most of them concern to studies developed in the Paraná (165 papers) followed by Tocantins (100) and Araguaia River basins (65). Seventeen papers were developed in two of these river basins and 2 papers in all three river basins. We also found two papers for the small portion of the São Francisco River basin occurring at Goiás State and one paper without any specific location, all of them were included in the main list.

Historically, the 322 papers were distributed between 1989-2018 and our findings pointed out to a slightly increase of fish papers' number since 1995 (Figure 1a). This temporal trend is pretty much like the variation in the number of authors and institutions over time, suggesting that the number of scientific papers published is related to the number of authors and institutions involved (Figure 1a). A similar trend was also observed for all the three river basins studied at Goiás State (Figure 1b, 1c and 1d) but with an expressive oscillation in the Araguaia River (Figure 1c), indicating that this tendency is spatially consistent independent of which basin is considered.

Scientific papers were related to nine different areas of knowledge: Conservation, Ecology, Education, Evolution, Fish Biology, Fisheries, Genetic, Pisciculture and Systematic/Taxonomy (Figure 2). Most of scientific papers published were related to Ecology (101 papers), Fish Biology (72) and Systematic/Taxonomy (89), followed by Genetic (44), Pisciculture (33), Evolution (15), Conservation (11), Education (2) and Fisheries (2), a trend that is also observed for each river basin separately (Figure 2). In the Paraná River basin, 53 papers (32.12\%) were related to Ecology, 52 (31.51\%) to Fish Biology, $31(18.78 \%)$ to Pisciculture and $24(14.54 \%)$ to Systematic/Taxonomy (Figure 2). In the Tocantins River basin, 47 papers (47\%) were related to Systematics/Taxonomy, 38 (38\%) to Ecology and
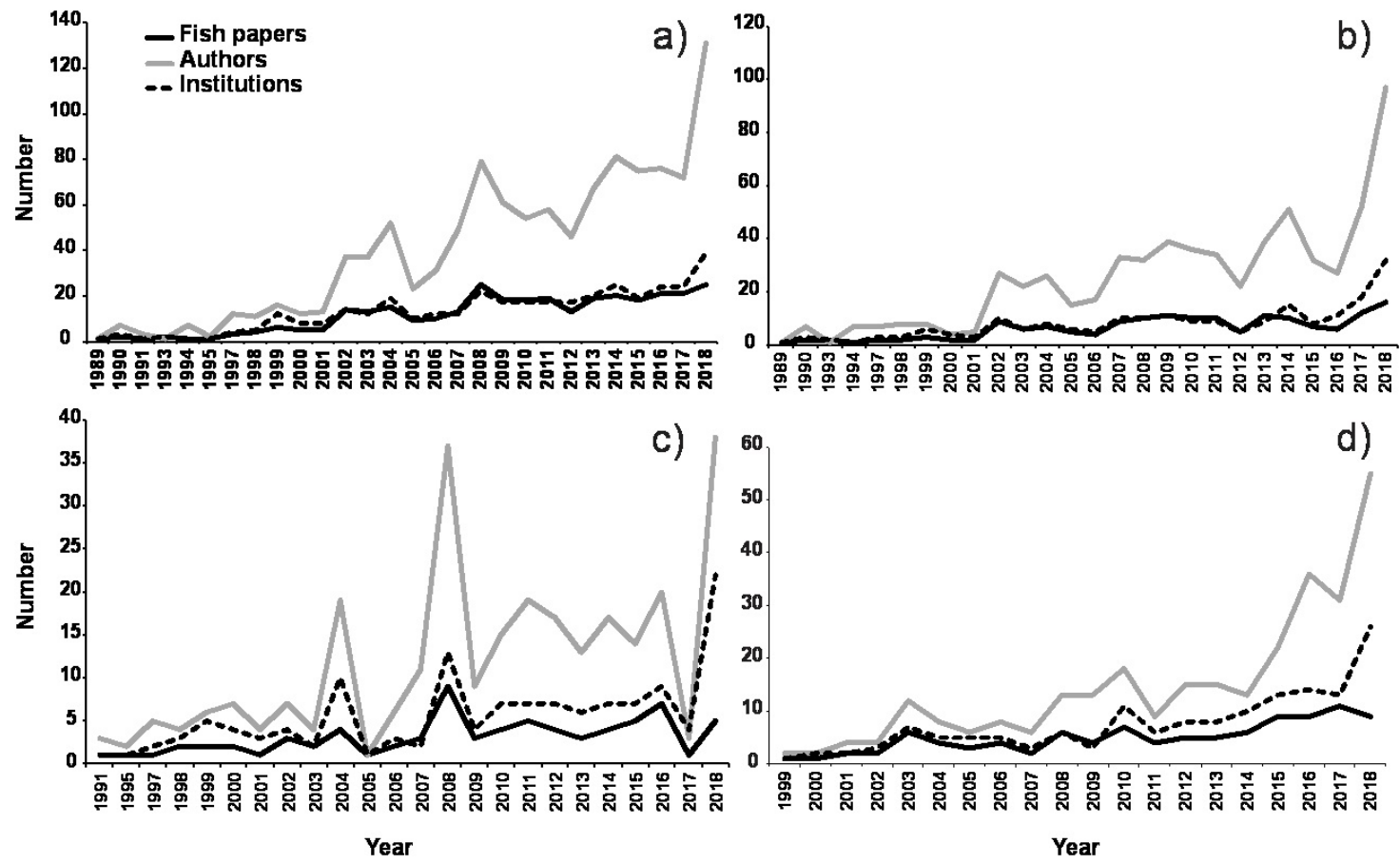

Figure 1. Temporal series of the number of freshwater fish papers, authors and institutions by all basins combined (a), Paraná (b), Araguaia (c) and Tocantins River basin (d) at Goiás State. 
$12(12 \%)$ to Fish Biology (Figure 2). In the Araguaia River basin, 25 papers (33.3\%) were related to Systematics/Taxonomy, 22 (29.3\%) to Genetic and $19(25.33 \%)$ to Ecology (Figure 2). These findings indicate the existence of research gaps in this region and point out to the concentration of some areas of knowledge in a single basin, as it is the case of the Paraná River basin that encompass 31 of the 33 papers associated to Pisciculture (Figure 2).
A great number of scientific papers were produced with the participation of academic institutions located inside Goiás State geopolitical boundaries, such as Universidade Federal de Goiás [Federal University of Goiás] (UFG, 72 papers), Pontifícia Universidade Católica de Goiás [Pontifical Catholic University of Goiás] (PUCGO, 45) and Universidade de Brasilia [University of Brasília] (UNB, 33; Figure 3a), but there is also participation

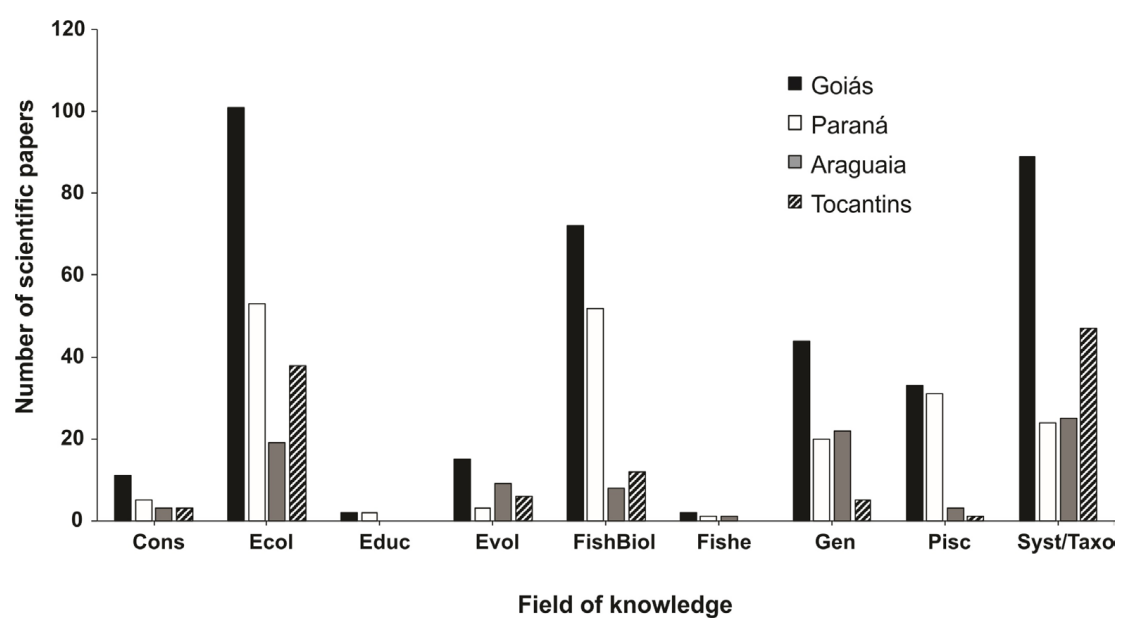

Figure 2. Number of scientific papers by field of knowledge and river basin in Goiás State. Cons=Conservation, Ecol=Ecology, Educ $=$ Education, Evol=Evolution, FishBiol=Fish Biology, Fishe=Fisheries, Gen=Genetic, Pisc=Pisciculture and Syst/Taxo=Systematics/Taxonomy.
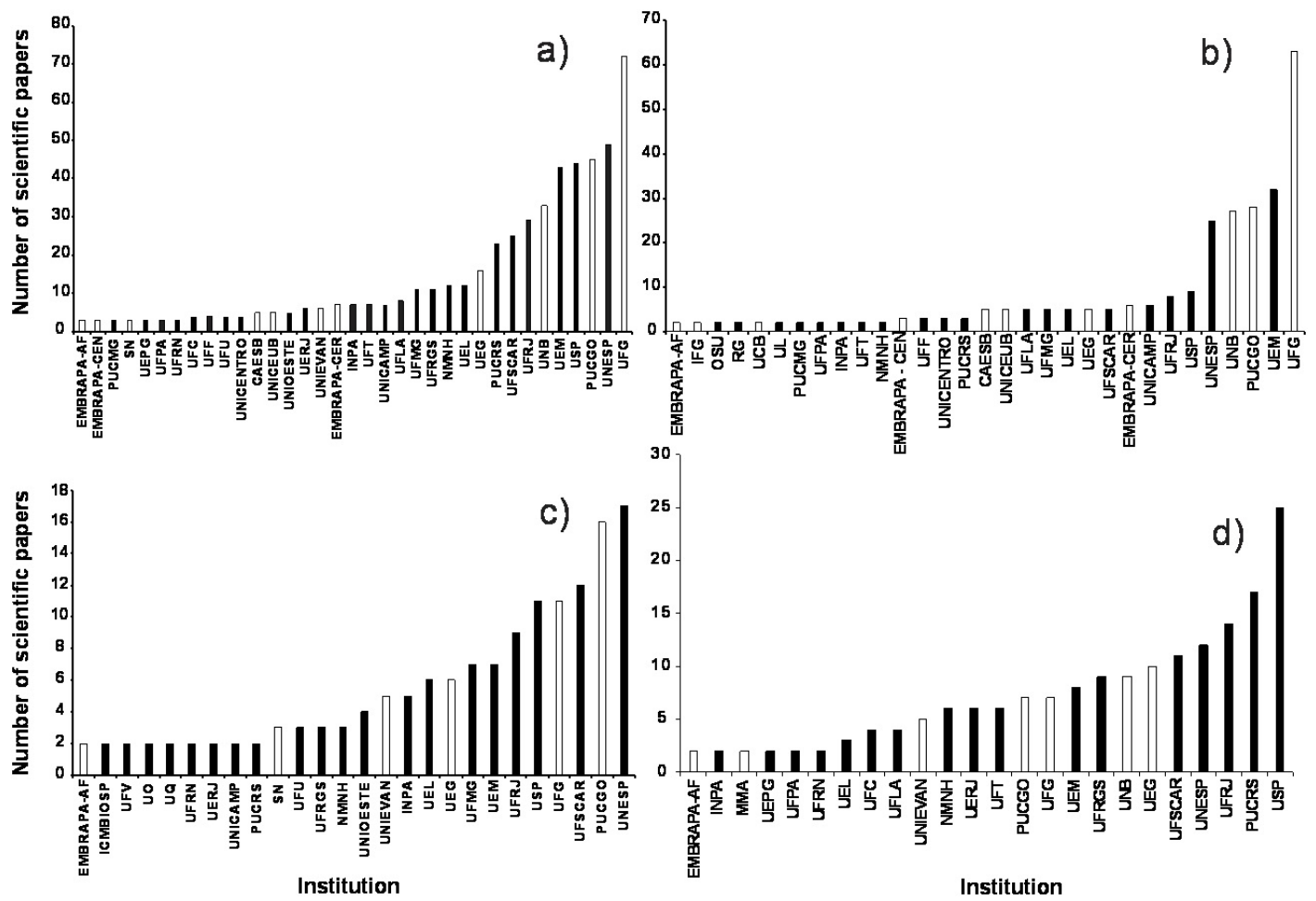

Figure 3. Number of scientific papers published per institution in all three basins combined (a), Paraná (b), Araguaia (c) and Tocantins River basin (d) in Goiás State. Institutions are identified according their location inside (white bars) or outside (dark bars) Goiás State. In (a) only institutions with three or more publications are displayed. 
of academic institutions located outside Goiás State geopolitical boundaries in this scientific production such as the Universidade Estadual Paulista [Paulista State University] (UNESP, 49), Universidade de São Paulo [University of São Paulo] (USP, 44), Universidade Estadual de Maringá [Maringá State University] (UEM, 43) and Universidade Federal do Rio de Janeiro [Federal University of Rio de Janeiro] (UFRJ, 29) as the main examples (Figure 3a). Nevertheless, the involvement of local institutions is mostly concentrated in the Paraná River basin, where the UFG participated in 63 papers, PUCGO in 28 and UNB in 27 (Figure 3b). In the Tocantins and Araguaia River basins, the participation of institutions located outside Goiás State geopolitical boundaries in the production of scientific papers is higher than local institutions (Figure $3 \mathrm{c}$ and $3 \mathrm{~d}$ ). An example of this situation is observed in the Tocantins River basin, where five institutions outside Goiás State has more participations in scientific papers that those located inside the geopolitical boundaries considered (Figure 3d).
Papers were published in 113 different journals, 47 of them without impact factor and 66 with impactor factor (ranging between 0.205-4.412, Table 1). Fifty papers were published in an international journal (Neotropical Ichthyology) supported by the Brazilian Association of Ichthyology (NI, Figure 4). Despite the high number of journals without impact factor and the concentration of several papers in a single journal, most papers seem to have achieved a broad audience in journals with good impact factor (Figure 4a; Table 1). Findings indicate that local institutions like UFG, PUCGO, UNB and UEG have a high proportion of publications in journals without impact factor when compared to institutions from outside Goiás State such as UNESP, USP, UEM, UFRJ and UFSCAR (Figure 4b; Table 1). A similar trend is observed for the number of papers published with(out) financial support per institution, that is, local institutions display higher number of papers without financial support than institutions located outside Goiás State geopolitical boundaries (Figure 4c).

Table 1. List of the scientific journals where freshwater fish papers related to Goiás State were published, their code (Figure 4a) and impact factor (IF, Scijournal.org, 2018).

\begin{tabular}{|c|c|c|}
\hline Scientific Journal & Code & IF \\
\hline Acta Limnologica Brasiliensia & ALB & NA \\
\hline Acta Scientiae Veterinariae & ASV & 0.217 \\
\hline Acta Scientiarum & ASC & NA \\
\hline Anais da Academia Brasileira de Ciências & AABC & 0.956 \\
\hline Anais da Escola de Agronomia e Veterinária & AEAV & NA \\
\hline Aqua International Journal of Ichthyology & AlJI & NA \\
\hline Aquaculture Nutrition & NA & 2.078 \\
\hline Aquatic Ecossystem Health \& Management & AEHM & 1.033 \\
\hline Aquatic Toxicology & AT & 3.884 \\
\hline Arquivos de Ciência da Saúde da Unipar & ACSU & NA \\
\hline Biochemical Genetics & BGEN & 1.927 \\
\hline Biochemical Systematics and Ecology & BSE & 0.847 \\
\hline Biological Invasions & $\mathrm{BI}$ & 3.054 \\
\hline Biological Research & BRE & 2.357 \\
\hline Biological Rhythm & $\mathrm{BRH}$ & 0.699 \\
\hline Bioscience Journal & BJ & 0.404 \\
\hline Biota Neotropica & $\mathrm{BN}$ & 0.842 \\
\hline Boletim de Geografia & BGEO & NA \\
\hline Boletim do Instituto de Pesca & BIP & 0.348 \\
\hline Boletim do Museu Paraense Emilio Goeldi & BMPEG & NA \\
\hline Brazilian Archives of Biology and Technology & BABT & 0.676 \\
\hline Brazilian Journal of Veterinary Research and Animal Science & BJVRAS & NA \\
\hline Brazilian Journal of Biology & BJB & 0.784 \\
\hline Brazilian Journal of Food Technology & BJFT & NA \\
\hline Bulletin of Environmental Contamination and Toxicology & BECT & 1.48 \\
\hline
\end{tabular}

NA=Not available. 
Table 1. Continued...

\begin{tabular}{|c|c|c|}
\hline Scientific Journal & Code & IF \\
\hline Caryologia & CARY & 0.608 \\
\hline Check List & $\mathrm{CL}$ & NA \\
\hline Chemico-Biological Interactions & $\mathrm{CBI}$ & 3.296 \\
\hline Ciência Animal Brasileira & $C A B$ & NA \\
\hline Comparative Cytogenetics & $\mathrm{CC}$ & 1.319 \\
\hline Computers and Industrial Engineering & $\mathrm{CIE}$ & 3.195 \\
\hline Copeia & $\mathrm{COP}$ & 1.22 \\
\hline Chromosome Research & $\mathrm{CR}$ & 2.909 \\
\hline Current Topics in Toxicology & CTT & NA \\
\hline Custos e Agronegócio & $C \& A$ & 0.205 \\
\hline Cybium & CYB & 0.346 \\
\hline Eclética Química & $E Q$ & NA \\
\hline Ecological Indicators & $\mathrm{El}$ & 3.983 \\
\hline Ecology of Freshwater Fish & EFF & 1.832 \\
\hline Ecotoxicology & ЕСОT & 1.987 \\
\hline Ecotoxicology and Environmental Contamination & EEC & NA \\
\hline Elo Diálogos em Extensão & ELO & NA \\
\hline Enciclopédia Biosfera & EB & NA \\
\hline Environmental Biology of Fishes & EBF & 1.514 \\
\hline Estudos & EST & NA \\
\hline Ethnoscientia & ETH & NA \\
\hline Evolução e Conservação da Biodiversidade & ECB & NA \\
\hline EVS & EVS & NA \\
\hline Food Analytical Methods & FAM & 2.245 \\
\hline Fragmentos de Cultura & FC & NA \\
\hline Freshwater Biology & FB & 3.767 \\
\hline Fronteiras: Journal of Social, Technological and Environmental Science & FRONT & NA \\
\hline Genetica & GENE & 1.366 \\
\hline Genetics and Molecular Biology & GMB & 1.493 \\
\hline Genetics and Molecular Research & GMR & NA \\
\hline Genome & GENO & 1.892 \\
\hline Hydrobiologia & HYDR & 2.165 \\
\hline Ichthyological Exploration of Freshwaters & IEF & 0.783 \\
\hline Iheringia Serie Zoologia & IHER & 0.294 \\
\hline Interdisciplinar: Revista Eletrônica da UNIVAR & INTER & NA \\
\hline International Journal of Agriculture and Environmental Research & IJAER & NA \\
\hline International Journal of Morphology & IJM & 0.336 \\
\hline International Journal of Speleology & IJS & 1.392 \\
\hline Journal of Applied Ichthyology & JAI & 0.774 \\
\hline Journal of Applied Toxicology & JAT & 2.909 \\
\hline Journal of Biogeography & $\mathrm{JB}$ & 4.154 \\
\hline Journal of Fish Biology & JFB & 1.702 \\
\hline Journal of Food Studies & JFF & NA \\
\hline Journal of Limnology & $\mathrm{JL}$ & 1.277 \\
\hline Journal of Morphology & $\mathrm{JM}$ & 1.711 \\
\hline Journal of the World Aquaculture Society & JWAS & 1.338 \\
\hline Journal of Toxicology and Environmental Health & JTEH & NA \\
\hline Lakes and Reservoirs: Research and Management & LRRM & NA \\
\hline Marine and Freshwater Research & MFR & 1.674 \\
\hline Mitochondrial DNA & MDNA & 0.925 \\
\hline
\end{tabular}

$\mathrm{NA}=$ Not available. 
Table 1. Continued...

\begin{tabular}{|c|c|c|}
\hline Scientific Journal & Code & IF \\
\hline Molecular Phylogenetics and Evolution & MPE & 4.412 \\
\hline Mutagenesis & MUTA & 2.84 \\
\hline Mutation Research & MR & 1.996 \\
\hline Natureza \& Conservação & NATCON & 2.766 \\
\hline Neotropical Ichthyology & $\mathrm{NI}$ & 1.216 \\
\hline Panamjas & PAN & NA \\
\hline Pesquisa Veterinário Brasileira & PVB & 0.385 \\
\hline Plos One & PLOS & 2.766 \\
\hline Proceedings of the Biological Society of Washington & PBSW & 0.563 \\
\hline PUBVET & PUBVET & NA \\
\hline Revista Agrarian & RAGR & NA \\
\hline Revista Ambiente \& Água & RAA & NA \\
\hline Revista Brasileira de Biologia & RBB & NA \\
\hline Revista Brasileira de Plantas Medicinais & RBPM & NA \\
\hline Revista Brasileira de Reprodução Animal & RBRA & NA \\
\hline Revista Brasileira de Zoologia & RBZOOL & NA \\
\hline Revista Brasileira de Zootecnia & RBZOOT & NA \\
\hline Revista da Biologia & RB & NA \\
\hline Revista de Biologia Tropical & RBT & 0.511 \\
\hline Revista de Ciências Agroveterinárias & $\mathrm{RCA}$ & NA \\
\hline Revista de química industrial & RQI & NA \\
\hline Revista Geográfica Venezolana & RGV & NA \\
\hline Revue Suisse de Zoologie & RSZ & 0.759 \\
\hline Scientia Agraria Paranaensis & SAP & NA \\
\hline Sodebras & SOD & NA \\
\hline Spixiana & SPIX & 0.375 \\
\hline Subterranean Biology & SB & NA \\
\hline Transactions of the American Fisheries Society & TAFS & 1.406 \\
\hline Tropical Zoology & $\mathrm{TZ}$ & 0.778 \\
\hline Veterinária Notícias & VN & NA \\
\hline Veterinary Parasitology & VP & 2.422 \\
\hline Zebrafish & ZEB & 1.733 \\
\hline ZooKeys & ZOOK & NA \\
\hline Zoologia & ZOOL & 0.723 \\
\hline Zoologica Scripta & ZOOS & 3.057 \\
\hline Zoological Journal of the Linnean Society & ZJLS & 2.685 \\
\hline Zoosystematics and Evolution & ZOOE & NA \\
\hline Zootaxa & ZOOT & 0.931 \\
\hline
\end{tabular}

$\mathrm{NA}=$ Not available.

Most financial support is granted from agencies from outside Goiás State, whereas the participation of local ones is smaller (Figure 5a-c). In all three river basins considered, the main funding agencies are the Conselho Nacional de Desenvolvimento Científico e Tecnológico [National Council for Scientific and Technological Development] (CNPq, a Brazilian government agency), Fundação de Amparo à Pesquisa do Estado de São Paulo [São Paulo Research Foundation] (FAPESP, a São Paulo State agency) and Coordenação de Aperfeiçoamento de Pessoal de Nivel Superior [Coordination for the Improvement of Higher Education Personnel] (CAPES, a Brazilian government agency; Figure 5a-c). In the Araguaia River basin, CNPq, FAPESP and CAPES were mentioned as founding agencies in 46, 20 and 16 papers, respectively, while the Universidade Estadual de Goiás [Goiás State University] (UEG) was mentioned twice (2 grants; Figure 5a). In the Tocantins River basin, CNPq, FAPESP and CAPES were mentioned as founding 
agencies in 70, 28 and 22 papers, respectively, while the Fundação de Amparo à Pesquisa do Estado de Goiás [Goiás Research Foundation] (FAPEG), a local institution, was mentioned in four papers

( 4 grants; Figure 5b). In the Paraná River basin,
CNPq, FAPESP and CAPES were mentioned in 90, 19 and 38 papers, respectively, while the local institution was Fundação de Amparo à Pesquisa do Distrito Federal [Federal District Research Foundation] (FAPDF, 7 grants; Figure 5c).

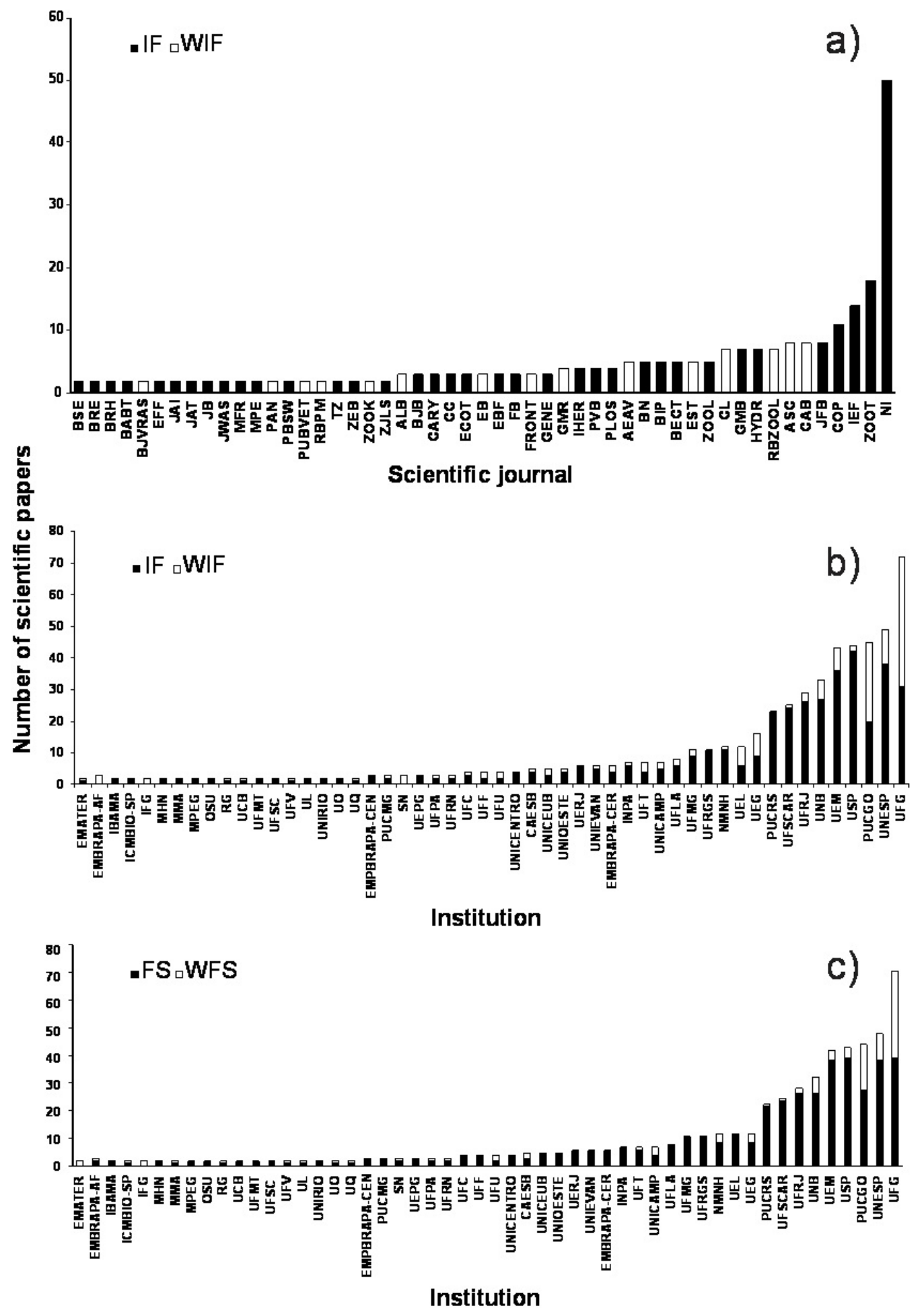

Figure 4. Number of scientific papers published per journal (a), institution and impact factor (b), and institution and financial support (c). IF= with impact factor; WIF=without impact factor; $F S=$ with financial support; WFS=without financial support. The full name of each journal is provided in Table 1. 


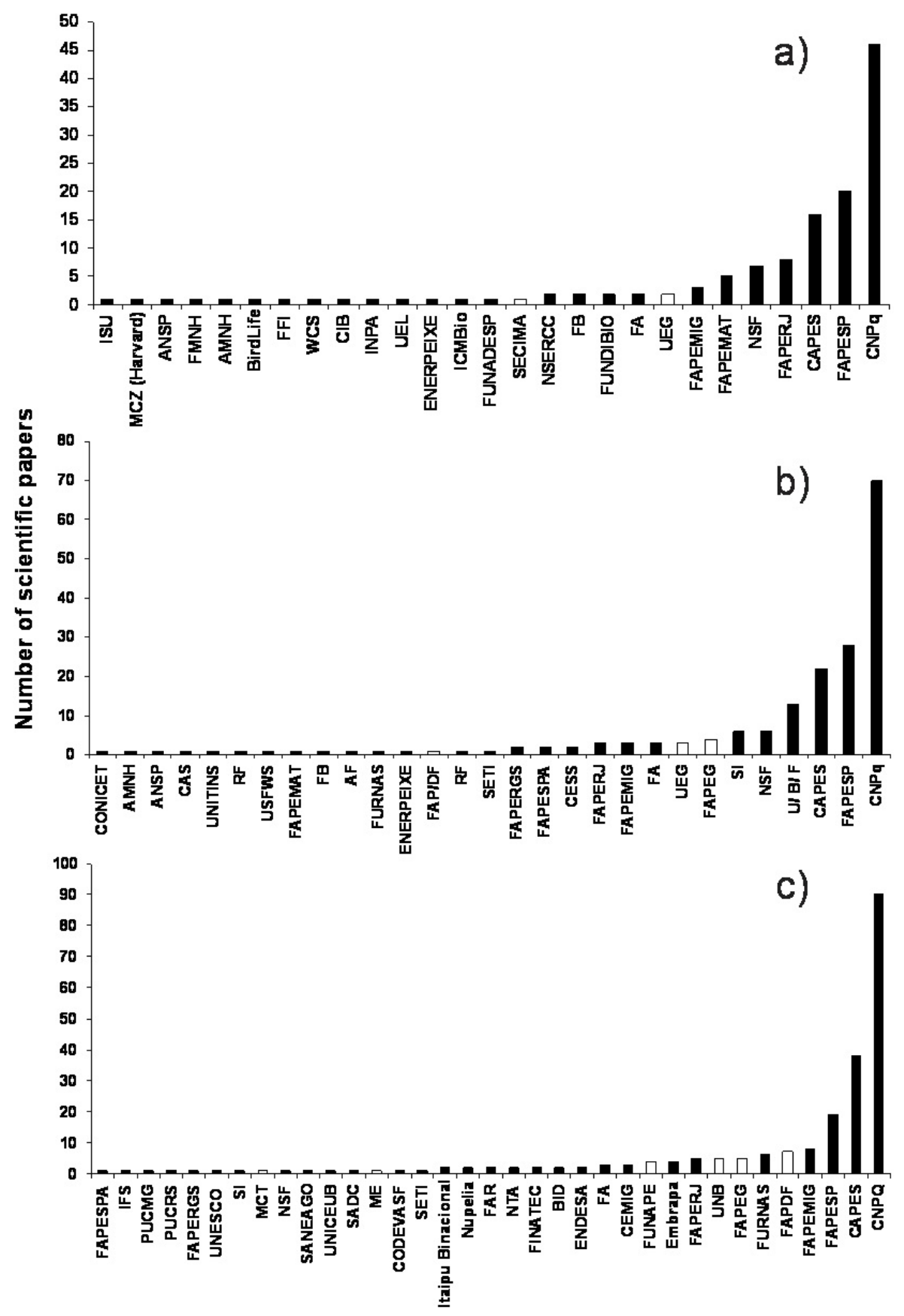

\section{Funding agency}

Figure 5. Number of scientific papers by funding agency's grants in the Araguaia (a), Tocantins (b) and Paraná River basin (c). Funding agencies or institutions are identified according their location inside (white bars) or outside (black bars) Goiás State.

\section{Discussion}

Despite biological boundaries and criteria are far much more applied in biological studies, political and economic interests are often guided by geopolitical borders which tend to overlap biological criteria (Diniz-Filho et al., 2008; Azevedo-Santos et al., 2017). Therefore, understanding the dynamic of studies over space and time inside geopolitical borders, such as those related to fish freshwater in Goiás State, may help scientists to fulfill existing gaps on biological research, and to maximize investments on future studies.

The number of scientific papers on Brazilian freshwater ichthyofauna went through a fast 
growth recently (Castro, 1999; Azevedo et al., 2010; Dias et al., 2016). Most of these papers are originated in Southeast, South and Midwest Brazilian regions because of their greater financial support, higher number of freshwater research teams and the easiest accessibility to watercourses by roads or trails (Azevedo et al., 2010; Dias et al., 2016). Over the last 30 years there was a tendency of increase in the number of freshwater ichthyology papers in Goiás State, located inside the Midwest region, Central Brazil, even though it has been slow and inconstant. This increase follows a similar trend observed for the Brazilian scientific production displayed by Barata (2017). We observed a coincidence between the papers' publication peaks and the increase of the authors and institutions number, which are in many cases from Southern and Southeastern Brazilian regions (e.g., papers conducted on the Araguaia and Tocantins River basins). The number of studies' oscillations over the last decades possibly reflects a regional asymmetry of the Brazilian scientific production with Southern and Southeastern regions hosting several research centers (undergraduate and graduate courses; Santos \& Azevedo, 2009) that fueled the national research. Despite recent state governmental efforts to minimize this asymmetry (Borges, 2010), such as the creation of the state research foundations (FAPEG in the case of Goiás State), this situation is still observed and encompasses different scientific knowledge areas (Dias et al., 2016). An example of this situation is the research project conducted in the Serra da Mesa reservoir, Tocantins River basin, and financed by FURNAS Centrais Elétricas [FURNAS Central Electric] (FURNAS). The project was coordinated by two Southeastern academic institutions (Universidade Federal do Rio de Janeiro [Federal University of Rio de Janeiro] - UFRJ and Universidade Estadual do Rio de Janeiro [Rio de Janeiro State University] - UERJ), and it was responsible for the production of several papers related to freshwater fish mainly between 2001 and 2010.

Most research knowledge areas in Brazilian freshwater fish papers between 1986 and 2005 were related to Genetic and Physiology fields, but Systematics, Morphology and Ecology were also the focus of many studies (Azevedo et al., 2010). On the other hand, Dias et al. (2016) showed that the main objectives of scientific papers about Brazilian stream fish assemblages were related to the Ecology field. A similar trend is observed for freshwater ichthyofauna scientific papers at Goiás
State, that is Ecology and Systematics/Taxonomy are the main fields of research followed by Fish Biology (Morphological, Physiological and Behavioral studies), Genetic and Pisciculture. The gaps are related to Conservation, Evolution, Education, and Fisheries fields. The difference of papers' number among knowledges fields is also evidenced among the river basins considered. Ecology fish papers are concentrated in the Paraná and Tocantins basins, whereas those related to Fish Biology, Genetic and Pisciculture fields are spatially concentrated in the Paraná and/or Araguaia River basins revealing that there are several spatial gaps in fish knowledge. The low number of Fisheries' papers observed is related to the commercial fishing prohibition in all watercourses of the Goiás State (Braudes-Araújo et al., 2016). Considering this scenario, investments and efforts of local government in fish studies should be taken in two different directions: 1) maintenance of the investments on studies focusing Ecology and Systematic/Taxonomic areas which form a baseline of conservation policies for freshwater environments (Dias et al., 2016), and help to minimize Linnean and Wallacean shortfalls (Whittaker et al., 2005; Olden et al., 2010); 2) increase its support to human resources and infrastructure for other areas that remain little explored, mainly Conservation and Education.

According to Nabout et al. (2015), much of the Brazilian scientific production is published in non-indexed journals with low impact, this is the case for many fish scientific papers published by researchers from all institutions involving fish collected in Goiás State. This situation seems to reflect in part the historical use of the Impact Factor as a metric to evaluate scientific production by Brazilian governmental institutions. Our dataset includes scientific papers before the year (1998) of adoption of this metric (Mugnaini, 2016). On the other side, the publication of scientific papers in non-indexed journals observed can be related to the researchers' choice of local/regional journals, normally without indexation, because of the results are relevant for their audience (Barata, 2017), claim of the Brazilian researchers' network to publish in local/regional journals to evite their closing (Petroianu, 2011; Grinberg et al., 2012), difficult to write in another language than Portuguese, and the absence of international collaboration (Packer, 2013). Despite that, the scientific production focusing on Goiás State fishes has achieved an international audience with publications in journals 
with high impact factor (1.003-4.412), but remains dependent on the Neotropical Ichthyology, an international journal supported by the Brazilian Association of Ichthyology.

Contemporary countries are organized according to geopolitical borders (states or provinces) that frequently define how financial resources are invested in scientific research. Despite these limits are not the most recommended scale for biological sciences, understanding spatial and temporal trends of studies inside geopolitical boundaries is important to guide future research and define local investments to increase knowledge. At Goiás State, we identified an asymmetry in the number of papers published on freshwater ichthyofauna over time, a pattern that is consistent for different hydrological basins in this region. Moreover, we also found that many fish scientific papers of local institutions were produced without any financial support, local investments in fish research are still incipient and several fields of knowledge remains little studied. Infrastructure, materials and human resources investments are necessary to maintain the growth of fish studies in this region and improve the knowledge in all fields of research. This is a crucial matter because fish species influence on the dynamics of food webs and nutrients recycling, the regulation of carbon flux from water to atmosphere, the ecosystem resilience, the redistribution of bottom substrates, the control of disease vectors and aesthetic and recreational human activities (Holmlund \& Hammer, 1999). Therefore, investing on fish research to improve our understanding about these organisms is not only a matter of science but of human welfare too. We believe that the approach used in this paper could be useful for other Brazilian states to identify their needs and to better allocate their resources in freshwater fish research.

\section{Acknowledgements}

Both authors are grateful to Pontifícia Universidade Católica de Goiás (PUCGoiás), Universidade Estadual de Goiás (UEG) and Centro Universitário de Anápolis (UniEVANGÉLICA) by support. RAC was supported by a scholarship (Bolsa de Incentivo à Produtividade - BIP) from UEG.

\section{References}

ALLAN, J.D., ERICKSON, D.L. and FAY, J. The influence of catchment land use on stream integrity across multiple spatial scales. Freshwater Biology, 1997, 37(1), 149-161. http://dx.doi. org/10.1046/j.1365-2427.1997.d01-546.x.
AZEVEDO, P.G., MESQUITA, F.O. and YOUNG, R.J. Fishing for gaps in science: A bibliographic analysis of Brazilian freshwater ichthyology from 1986 to 2005. Journal of Fish Biology, 2010, 76(9), 2177-2193. http://dx.doi.org/10.1111/j.10958649.2010.02668.x. PMid:20557658.

AZEVEDO-SANTOS, V.M., FEARNSIDE, P.M., OLIVEIRA, C.S., PADIAL, A.A., PELICICE, F.M., LIMA JUNIOR, D.P., SIMBERLOFF, D., LOVEJOY, T.E., MAGALHÁES, A.L.B., ORSI, M.L., AGOSTINHO, A.A., ESTEVES, F.A., POMPEU, P.S., LAURANCE, W.F., PETRERE JUNIOR, M., MORMUL, R.P. and VITULE, J.R.S. Removing the abyss between conservation science and policy decisions in Brazil. Biodiversity and Conservation, 2017, 26(7), 1745-1752. http:// dx.doi.org/10.1007/s10531-017-1316-x.

BARATA, G. Em revisão: o impacto da produção científica brasileira para o Brasil. Ciência e Cultura, 2017, 67(4), 6-8. http://dx.doi.org/10.21800/231766602015000400003.

BORGES, M.N. As fundaçóes estaduais de amparo à pesquisa e o desenvolvimento da ciência, tecnologia e inovação no Brasil. Revista USP, 2010, (89), 174-189.

BRAUDES-ARAÚJO, N., DE CARVALHO, R.A. and TEJERINA-GARRO, F.L. Amateur fishing and tourism in the middle Araguaia River, Central Brazil. Fronteiras: Journal of Social, Technological and Environmental Science, 2016, 5(3), 136-150.

BRAUDES-ARAÚJO, N., TEJERINA-GARRO, F.L. and DE CARVALHO, R.A. Biodiversidade de peixes na bacia hidrográfica Tocantins-Araguaia, Brasil. In: S.C. MIRANDA, P. S. DE-CARVALHO and A.A. RIBON, orgs. Tópicos em Manejo e conservação do cerrado: biodiversidade, solos e uso sustentável. Goiânia: Kelps, 2019, pp. 109-166.

BUCKUP, P.A., MENEZES, N.A. and GHAZZI, M.S., eds. Catálogo das espécies de peixes de água doce do Brasil. Rio de Janeiro: Museu Nacional, 2007.

CARVALHO, R.A. and TEJERINA-GARRO, F.L. Relationships between taxonomic and functional components of diversity: Implications for conservation of tropical freshwater fishes. Freshwater Biology, 2015, 60(9), 1854-1862. http://dx.doi. org/10.1111/fwb.12616.

CASATTI, L. Alteraçôes no Código Florestal Brasileiro: impactos potenciais sobre a ictiofauna. Biota Neotropica, 2010, 10(4), 31-34. http://dx.doi. org/10.1590/S1676-06032010000400002.

CASTRO, R.M.C. Evolução da ictiofauna de riachos sul-americanos: padróes gerais e possíveis processos causais. In: E.P. Caramaschi, R. Mazzoni and P.R. Peres-Neto, eds. Ecologia de peixes de riachos. Rio de Janeiro: PPGE-UFRJ, 1999, pp. 139-155. http:// dx.doi.org/10.4257/oeco.1999.0601.04. 
CONSELHONACIONALDEDESENVOLVIMENTO CIENTÍFICO E TECNOLÓGICO - CNPq. [online]. Brasília: CNPq, 2018 [viewed 1 Jan. 2018]. Available from: http://lattes.cnpq.br/

DELGADO-LÓPEZ-CÓZAR, E. and REPISOCABALLERO, R. The impact of communication journals: Comparing Google scholar metrics, web of science and scopus. Comunicar, 2013, 21(41), 45-52. http://dx.doi.org/10.3916/C41-2013-04.

DIAS, M.S., ZUANON, J., COUTO, T.B.A., CARVALHO, M., CARVALHO, L.N., ESPÍRITO-SANTO, H.M.V., FREDERICO, R., LEITÃO, R.P., MORTATI, A.F., PIRES, T.H.S., TORRENTE-VILARA, G., VALE, J., ANJOS, M.B., MENDONÇA, F.P. and TEDESCO, P.A. Trends in studies of Brazilian stream fish assemblages. Natureza \& Conservaçâo, 2016, 14(2), 106-111. http://dx.doi.org/10.1016/j.ncon.2016.06.003.

DINIZ-FILHO, J.A.F., BINI, L.M., VIEIRA, C.M., BLAMIRES, D., TERRIBILE, L.C., BASTOS, R.P., DE OLIVEIRA, G. and BARRETO, B S. Spatial patterns of terrestrial vertebrate species richness in the Brazilian Cerrado. Zoological Studies (Taipei, Taiwan), 2008, 47(2), 146-157.

FEARNSIDE, P.M. Belo Monte: actors and arguments in the struggle over Brazil's most controversial Amazonian dam. Die Erde, 2017, 148(1), 14-26.

FERREIRA, J., ARAGÁO, L.E.O.C., BARLOW, J., BARRETO, P., BERENGUER, E., BUSTAMANTE, M., GARDNER, T.A., LEES, A.C., LIMA, A., LOUZADA, J., PARDINI, R., PARRY, L., PERES, C.A., POMPEU, P.S., TABARELLI, M. and ZUANON, J. Brazil's environmental leadership at risk. Science, 2014, 346(6210), 706-707. http://dx.doi.org/10.1126/ science.1260194. PMid:25378611.

FROESE, R. and PAULY, D., editors. FishBase [online]. 2018 [viewed 1 Jan. 2019]. Available from: https:// www.fishbase.org

GRINBERG, M., SOLIMENE, M.C. and BARRETO, M.C. Por que publicar em periódicos nacionais? Arquivos Brasileiros de Cardiologia, 2012, 98(3), E62-E63. PMid:22527023.

HANSEN, M.C., POTAPOV, P.V., MOORE, R., HANCHER, M., TURUBANOVA, S.A., TYUKAVINA, A., THAU, D., STEHMAN, S.V., GOETZ, S.J., LOVELAND, T.R., KOMMAREDDY, A., EGOROV, A., CHINI, L., JUSTICE, C.O. and TOWNSHEND, J.R.G. High-resolution global maps of 21st-century forest cover change. Science, 2013, 342(6160), 850 853. http://dx.doi.org/10.1126/science.1244693. PMid:24233722.

HOLMLUND, C.M. and HAMMER, M. Ecosystem services generated by fish populations. Ecological Economics, 1999, 29(2), 253-268. http://dx.doi. org/10.1016/S0921-8009(99)00015-4.
LEWINSOHN, T.M. and PRADO, P.I. How many species are there in Brazil? Conservation Biology, 2005, 19(3), 619-624. http://dx.doi.org/10.1111/j.15231739.2005.00680.x.

LOYOLA, R. Brazil cannot risk its environmental leadership. Diversity \& Distributions, 2014, 20(12), 1365-1367. http://dx.doi.org/10.1111/ddi.12252.

MAGALHÁES, A.L., CASATTI, L. and VITULE, J.R.S. Changes in the Brazilian Forest Law will promote non-native species of freshwater fish. Natureza \& Conservação, 2011, 9, 221-224.

METZGER, J.P., LEWINSOHN, T.M., JOLY, C.A., VERDADE, L.M., MARTINELLI, L.A. and RODRIGUES, R.R. Brazilian law: full speed in reverse? Science, 2010, 329(5989), 276-277. http:// dx.doi.org/10.1126/science.329.5989.276-b. PMid:20647446.

MITTERMEIER, R.A., MITTERMEIER, C.G. and ROBLES-GIL, P. Megadiversity: earth's biologically wealthiest nations. México: Agrupación Serra Madre, 1997.

MOSS, B. Biodiversity in fresh waters - an issue of species preservation or system functioning? Environmental Conservation, 2000, 27(1), 1-4. http://dx.doi. org/10.1017/S0376892900000011.

MUGNAINI, R. O Fator de Impacto: sua popularidade, seus impactos e a necessidade de preservação do processo de geração do conhecimento científico. Revista da Escola de Enfermagem da USP, 2016, 50(5), 720-721. PMid:27982388.

NABOUT, J.C., CARNEIRO, F.M., BORGES, P.P., MACHADO, K.B. and HUSZAR, V.L.M. Brazilian scientific production on phytoplankton studies: national determinants and international comparisons. Brazilian Journal of Biology $=$ Revista Brasileira de Biologia, 2015, 75(1), 216-223. http://dx.doi.org/10.1590/1519-6984.11713. PMid:25945640.

OLDEN, J.D., KENNARD, M.J., LEPRIEUR, F., TEDESCO, P.A., WINEMILLER, K.O. and GARCÍA-BERTHOU, E. Conservation biogeography of freshwater fishes: recent progress and future challenges. Diversity \& Distributions, 2010, 16(3), 496-513. http://dx.doi.org/10.1111/j.14724642.2010.00655.x.

PACKER, A.L. Os periódicos brasileiros e a comunicação da pesquisa nacional. Revista USP, 2013, 0(89), 26. http://dx.doi.org/10.11606/issn.2316-9036. v0i89p26-61.

PETROIANU, A. Perversidade contra a publicação médica no Brasil. Revista do Colégio Brasileiro de Cirurgióes, 2011, 38(5), 290-370. http:// dx.doi.org/10.1590/S0100-69912011000500001. PMid:22124637.

POLLARD, P. and HUXHAM, M. The European Water Framework Directive: a new era in the management 
of aquatic ecosystem health? Aquatic Conservation, 1998, 8(6), 773-792. http://dx.doi.org/10.1002/ (SICI) 1099-0755(1998110)8:6<773::AIDAQC313>3.0.CO;2-R.

SANTOS, A.L.F. and AZEVEDO, J.M.L. A pósgraduaçáo no Brasil, a pesquisa em educação e os estudos sobre a política educacional: os contornos da constituição de um campo acadêmico. Revista Brasileira de Educação, 2009, 14(42), 534-550. http://dx.doi. org/10.1590/S1413-24782009000300010.

SANTOS, S.M.S.B.M. and HERNANDEZ, F.M. Painel de especialistas: análise crítica do estudo de impacto ambiental do aproveitamento hidrelétrico de Belo Monte. Belém: [s.n.], 2009.

SCARANO, F., GUIMARÁES, A. and SILVA, J.M. Lead by example. Nature, 2012, 486(7401), 25-26. http:// dx.doi.org/10.1038/486025a. PMid:22678263.

SCIJOURNAL.ORG. Impact factor lists [online]. USA: International Scientific Institute, 2018 [viewed 27 June 2018]. Available from: https://www.scijournal. org/index.html
SOARES-FILHO, B., RAJÃO, R., MACEDO, M., CARNEIRO, A., COSTA, W., COE, M., RODRIGUES, H. and ALENCAR, A. Cracking Brazil's Forest Code. Science, 2014, 344(6182), 363 364. http://dx.doi.org/10.1126/science. 1246663. PMid:24763575.

TEJERINA-GARRO, F.L., CARVALHO, R.A. and TERESA, F.B. A biodiversidade e a conservação da ictiofauna do alto da bacia do rio Paraná no estado de Goiás, Brasil Central. In: W. HANNIBAL, R.F. ROSSI, I.L. MORAIS and L.H.M. TEIXEIRA, eds. Biodiversidade, manejo e conservação do Sul de Goiás. Jundiaí: Paco Editorial, 2017.

WHITTAKER, R.J., ARAÚJO, M.B., JEPSON, P., LADLE, R.J., WATSON, J.E.M. and WILLIS, K.J. Conservation biogeography: assessment and prospect. Diversity \& Distributions, 2005, 11(1), 3-23. http:// dx.doi.org/10.1111/j.1366-9516.2005.00143.x.

Received: 17 August 2018 Accepted: 28 August 2019 